\title{
English Competence of Generation Z: A Study at IAIN Kudus
}

\author{
${ }^{1}$ Azizah Maulina Erzad, ${ }^{2}$ Lusi Ardanisa Mei Clarita, and ${ }^{3}$ Yunita Salma \\ 1,2,3 IAIN Kudus Jl. Conge Ngembalrejo 51, Bae, Kudus, Jawa Tengah, Indonesia \\ (azizahmaulina@iainkudus.ac.id)
}

Article History: Submitted December $26^{\text {th }}, 2019$; Accepted January $14^{\text {th }}, 2020$; Published March $13^{\text {th }}, 2020$

\begin{abstract}
Industrial revolution 4.0 era which is also called as disruptive era gives many benefits for several aspects especially in education. It becomes easier for the teacher to use any kinds of media for teaching English and for the students to find English materials by themselves. The recent students of English Education Department IAIN Kudus belong to generation $\mathrm{Z}$ students. As generation $\mathrm{Z}$ students who live in 4.0 era, they are able to access many kinds of information or knowledge and improve their English competences from any resources easily. This paper aims to identify the way of the generation $\mathrm{Z}$ learn English, the difficulties encountered by them in learning English, and the solutions or suggestions to overcome the difficulties. This study employed mixed methods research. In conducting this research, the researchers used observation, open-ended questionnaire and documentation to collect the data. The participants were 39 students of English Education Department at IAIN Kudus. The results showed that $60 \%$ students use gadgets to study English, $15 \%$ use books, and $25 \%$ use both of them. Meanwhile, 50\% students have difficulties in speaking, $10 \%$ in listening, $6 \%$ in reading, $17 \%$ in writing, and $17 \%$ in those four competences. Some solutions or suggestions were revealed to resolve the difficulties. The solutions were extended for each language competence.
\end{abstract}

Keywords: English Competence, Generation Z, IAIN Kudus

\begin{abstract}
Abstrak. Era revolusi industri 4.0, yang juga dikenal dengan era disruptif, memberikan banyak keuntungan dalam berbagai aspek khususnya dalam pendidikan. Hal ini akan memudahkan guru untuk menggunakan berbagai jenis media untuk mengajar Bahasa Inggris dan juga bagi mahasiswa untuk mencari materi Bahasa Inggris sendiri. Mahasiswa jurusan Bahasa Inggris IAIN Kudus juga termasuk mahasiswa generasi Z. Sebagai mahasiswa generasi $Z$ yang tinggal di era 4.0, mereka mampu mengakses berbagai macam informasi atau pengetahuan untuk memperbaiki kompetensi mereka dari berbagai sumber dengan mudah. Paper ini bertujuan untuk mengidentifikasi cara bagaimana generasi Z belajar Bahasa Inggris, kesulitan-kesulitan yang dihadapi mereka, dan solusi atau saran untuk menghadapi kesulitan tersebut. Penelitian ini menggunakan metode campuran (mixed methods), dan dalam mengumpulkan data penulis menggunakan teknik observasi, kuesioner, dan dokumentasi. Peserta penelitian ini adalah 39 mahasiswa jurusan Bahasa Inggris IAIN Kudus. Hasil menunjukkan bahwa cara mereka belajar $60 \%$ menggunakan gawai, $15 \%$ menggunakan buku, dan $25 \%$ menggunakan dua-duanya. $50 \%$ mahasiswa mengalami kesulitan dalam berbicara Bahasa Inggris, $10 \%$ mendengarkan, $6 \%$ dalam membaca, $17 \%$ dalam menulis, dan $17 \%$ mengalami kesulitan dalam keempat-empatnya. Beberapa solusi ditawarkan untuk menghadapi masalah tersebut, terutama di masing-masing keahlian berbahasa.
\end{abstract}

Kata kunci: kompetensi bahasa Inggris, generasi Z, IAIN Kudus 


\section{INTRODUCTION}

Education is an important thing and very needed by all people. Nowadays, almost young generation continue their study to a higher education. They are very enthusiastic to study in university in order to be well-educated. This era has forced them to be literate persons. Besides that, studying in university becomes a prestige for most of people. Some parents will be proud if they are able to send their children to university. Therefore, many universities accept students in a large number recently.

Unlike the situation in the past, many parents less aware of the importance of higher education for their children. Besides lack of awareness, parents were reluctant to send their children to college because of the school fee which they couldn't afford. It happened especially in rural areas where most of the economic level of the community is middlelow. As a result, many parents were not able to send their children to college.

In this industrial revolution 4.0 era, the parents should aware to the importance of education for their children especially higher education. The young generation should be well-educated in order to get a good job in this era. Furthermore, higher education is also benefit for their future not only to get a job but also to educate their own children. It is clear that education is important for our lives. The main objective of education is to get knowledge, develop self-skills, and to lead a successful life. In addition, having an adequate education will give contribution for themselves, family, society, nation, and humanity.

Due to many benefits of education, both parents and children should have concern for this issue. Many scholarships can be applied for those who live in rural areas and have and have a problem in finance. Parents and children can also choose the cheapest college which they can afford. There are many colleges or universities with affordable school fees. Thus, it's easy to get education in college or university nowadays.

The existence of many colleges or universities and scholarships recently brings a significant impact on people's interests in going to college. It is also caused by a reason that many parents and young generations realize the importance of education at university. The young generations' interests to continue their study in higher education are also influenced by the sophisticated technology in this era. This disruptive era has changed their mindsets to be more educated.

Every aspect in our lives is closely related to technology. It can't be denied that people can't be separated with their gadgets like smartphone, laptops, tablets, and many more. It is already be a part of people's need and lifestyle. Technology has reached all aspects of life. One of them is the education sector.Various kinds of technology have been widely used in education. All learning materials are also increasingly accessible to everyone by using technology. The young generation who are very familiar with technology will find it easier to learn everything.

The sophisticated technology and the easiness to access information require the young generations to develop their potentials. It is no wonder that today many young generations enroll themselves to a college or university. Parents are also well aware to send their children to college today. In fact, some universities also accept large numbers of new students due to the high interests. 
Nowadays, most of the students in college come from different generation with the previous generation. Large numbers of students in universities consist of various generations. There are generation X (born among 1965-1979), generation Y or millennial (born among 1980-1995), and generation $Z$ (born among 1996-2014). In university we may find generation $X$ that is part of graduate students. Generation $Y$ or Millennial is final year of undergraduate students and Generation $\mathrm{Z}$ students are students in the early years of the undergraduate program. While university lecturers belong to the baby boomers generation (born among 1946-1964). It can be seen that there is a significant contradiction among the lecturers and students.

Students who were born as generation $\mathrm{Z}$ should be more educated. As stated by Suganda (2018: 1-11) that due to the development of technology, every generations influences the learning process. Generation $\mathrm{Z}$ is generation who lives in modern era in which the technology is so sophisticated. Generation $\mathrm{Z}$ students are able to use and operate various kinds of media including handphone, internet, and so on. From the quotation above, it can be concluded that generation $\mathrm{Z}$ with their characteristics will change or influence the learning process. It will also change the learning method or their ways to study.

Since the generation $\mathrm{Z}$ students are so easy to access many kinds of information and knowledge from any resources, they must be cleverer than the previous generations. They are so familiar with the sophisticated technology. They have smartphones, tablets, laptops, and other handy gadgets. As digital natives, they have their own characteristics, attitudes, needs, and attributes (2019: 2804-2012). Knowing their unique characteristics, they may have a different learning style as well. If they use their gadgets properly especially for education, they must be cleverer than the previous generations. In addition, the use of foreign language especially English which has a role as international language is very important and needed in this disruptive era. English mastery must be owned by the generation $\mathrm{Z}$ students. By using technology, generation $\mathrm{Z}$ students should improve their English competence since they can train their skills such as listening, speaking, reading, and writing easily from the internet.

The word competence refers to ability or knowledge while the word communicative means exchange or interaction (Ahmed and Pawar, 2018). Then both of them concluded that communicative competence is having the ability that allows the person to communicate in order to fulfill communicative needs. In other words, communicative competence can be defined as possessing a competence to communicate.

Meanwhile, Saville-Troike (2006) defines the communicative competence as "everything that a speaker needs to know in order to communicate appropriately within a particular community." So, it can be defined as the ability to use English and to interact in oral and written communication. The ability to use English in oral and written communication is covered in four language skills. Those skills are listening, speaking, reading, and writing. Thus, the English competence in this study will only focus on four English skills.

English competence or skills are very important for English learners especially English Education Department students. English Education Department students are students who study English in order to be English teachers. Yufrizal (2017) explained that those students should possess the communicative competence in order to be able to master the pedagogic competence and other professional subject. Therefore, they should have adequate English skills such as listening, speaking, reading, and writing. In language classroom, four skills give many valuable purposes. Those purposes are giving learners scaffolded support, 
opportunities to create, contexts in which to use the language for exchanges of real information, evidence of their own ability (proof of learning) and, most important, confidence (Sadiku, 2015).

English which is as an international language and used to communicate in all aspects, must be mastered by generation Z. Generation Z students are able to learn English from any resources which are related to technology, for example internet. They have sophisticated and handy gadget to access various English materials and train their language skills. Although they can learn English easily by using technology, they may have problems or difficulties also in learning English as encountered by previous generations. The difficulties may be a bit different with the problems faced by the previous generations.

By conducting this study in English Department at IAIN Kudus, the researchers are eager to know the English competence of generation $\mathrm{Z}$ students especially English students. The difficulties or problems encountered by generation $\mathrm{Z}$ students in learning English will also be revealed. The researchers will compile some solutions or alternatives to resolve the problems. For those above reasons, the researchers will conduct a study entitled "English Competence of Generation Z: A Study at IAIN Kudus".

\section{METHOD}

In this study, the researchers used mixed methods study. According to Sugiyono (2015), mixed methods research is a research method that combines quantitative methods and qualitative methods. Meanwhile, Creswell in Sugiyono (2015) stated that "a mixed methods design is useful when either the quantitative or qualitative approach by itself is inadequate to best understand a research problem or the strengths of both quantitative and qualitative research can provide the best understanding". It is clear that the use of mixed methods is in order to get best understanding of research problems.

There two main models in mixed methods research. Those are sequential model and concurrent model. The sequential model is divided into two models: sequential explanatory and sequential exploratory. This study used sequential explanatory. Sequential explanatory refers to the use of quantitative and qualitative methods which are combined in a sequence. Creswell in Sugiyono (2015) explained that "explanatory strategy in mixed methods research is characterized by the collection and analysis of quantitative data in a first phase followed by the collection and analysis of qualitative data in a second phase that build on the result of initial quantitative results." Thus, in this study, the researchers collect and analyze the quantitative data in the first phase and followed by the activity to collect and analyze the qualitative data in the second phase to support and give additional information on the result of quantitative results.

This research was conducted at IAIN Kudus, especially focus on the English Department Students in Tarbiyah Faculty. The populations of this research are students of English Education Department IAIN Kudus. Meanwhile, the subjects of the research are the third semester students of English Education Department IAIN Kudus. The number of population in this study is 110 students. As stated by Arikunto (2010), "if the subject is less than 100 , then it is better to take all of it so that the research is a population study. Furthermore, if the subject is more than 100 , it can be taken between $10-15 \%$ or $20-25 \%$ or more". The researchers take the sample 35\% from the population. So, the number of the sample is 39 students of English Department Students. 
The researchers used several techniques of data collection. Those are observation, questionnaire, and documentation.

\section{RESULTS AND DISCUSSION}

\section{Results}

\section{The ways of generation $Z$ of English Education Department students at IAIN Kudus} learn English

There are many ways to learn English. The students can use some media to improve their abilities in English. As generation Z, the students often use the technology to learn English. They use their gadgets to improve their English competence including listening, speaking, reading, and writing. They use modern media as they live in industrial revolution era 4.0. By using their gadgets, they access some applications through internet.

Based on the result of questionnaires, the media that they use to improve their English competence are different with the previous generations. In this millennial era, most of the students prefer to use gadget than books as their media to learn English. Meanwhile, there are also some students who use both gadgets and books to learn English. It can be seen in the figure below.

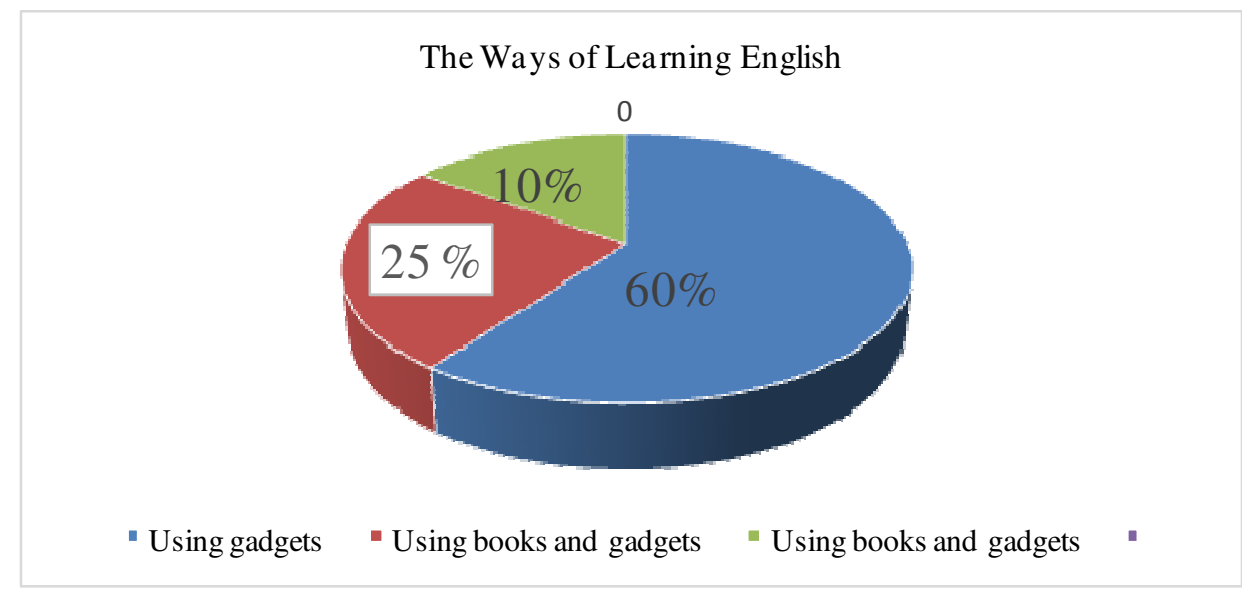

Figure 1 The Ways of English Department Students in Learning English

It can be seen in the figure 1 above that 23 students or $60 \%$ of English Department students use gadgets to study English. According to the result of questionnaires, most of them learn English through social media by accessing the internet. The common social media used by the students are instagram, YouTube, twitter, facebook, line, and whatsApp. Besides social media, they also use e-book which they get from the internet to learn English.

The second way to learn English is by using gadgets and books. There is around $25 \%$ of English Department students or 10 students use gadgets and books. The students combined both of them (book and gadget) to get better knowledge in English.

The third way is using book to learn English. There are some students which only use books as their media to study. It is around 15\% of English Department students or 6 
students using that media. They said that book is their source of knowledge, and they prefer to use it because of it will not make their eyes easy to tired.

From the results, it can be said that although generation $\mathrm{Z}$ is digital native, some of the gen $\mathrm{Z}$ students still use book as their media to study. Moreover, the others also still use book as a media to study and combine it with the use of gadgets especially smartphones. They use both of them in order to get complete knowledge and materials of English. Nevertheless, the use of gadgets for learning English gets the highest percentage in this study.

\section{The difficulties in learning English encountered by Generation $Z$ of English Education Department students at IAIN Kudus}

The generation $\mathrm{Z}$ students who are digital native also face some problems in learning English. There are some problems or difficulties encountered by the students in learning English. Those difficulties are including the English competence such as listening, speaking, reading, and writing. The detailed information is as follows.

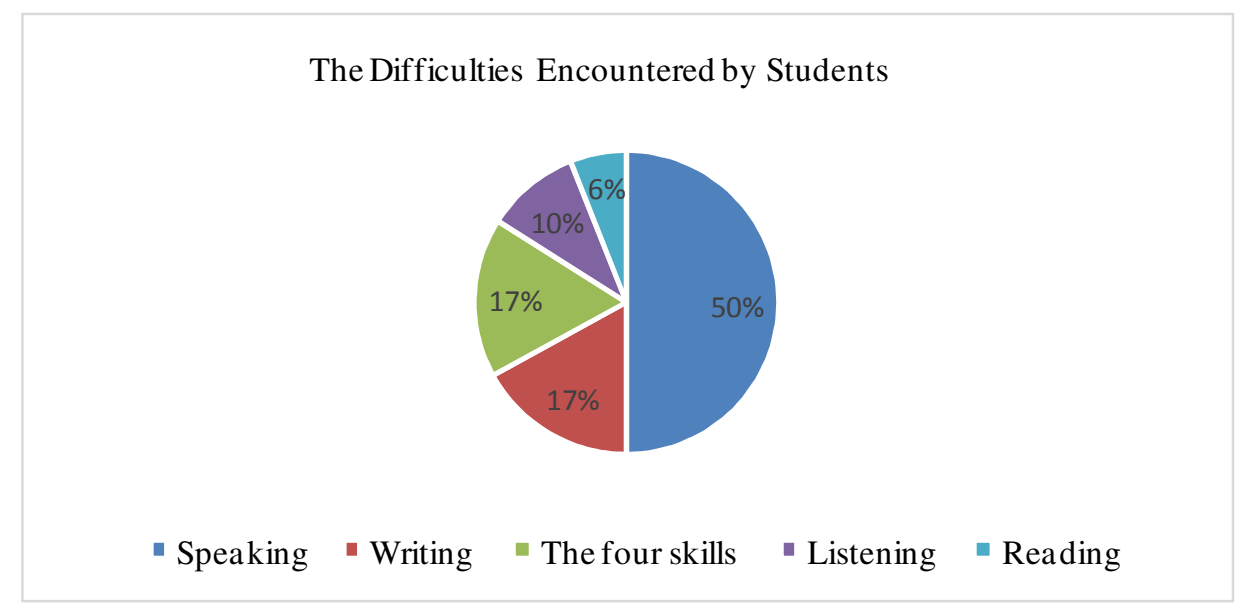

Figure 2 The difficulties encountered by the students in learning English

From the Figure 2 above, it can be concluded that there are five aspects of problems faced by the students. Those five aspects include the four English skills and the last aspect is the combination of all skills. The specific data are explained below.

a. The first problem is the students have difficulty in speaking. It is $50 \%$ of the students or 20 students. Some of the students are lack in vocabulary. Some of them are confuse what should they speak because they don't know the grammar, they are not good at grammar.

b. The second problem is the difficulty in writing. There are $17 \%$ of the students or 7 students faced this problem. They are confused how to arrange the words well. Because they do not master the grammar well so they confuse how to write a good text.

c. The third problem is the difficulty in those four skills. There are $17 \%$ of the students or 7 students have a problem in four of them such as listening, speaking, reading, and writing.

d. The fourth is listening. There are 4 students or $10 \%$ of the students have a problem in listening skill. They said that listening is difficult to understand because of the speaker, the sound of the speakers is always change, and have different way in pronouncing. 
e. The last is reading. There is 1 student or only $6 \%$ of the students who has problem in reading skill. The reason is because they don't know how to spell it and pronounce it well. There are some vocabularies are the same to pronounce it, sometimes they confuse with it.

\section{The solutions to overcome the difficulties given to Generation $\mathrm{Z}$ of English Education Department students at IAIN Kudus}

The problems faced by the students should be solved soon by them in order not to bother their activities in learning English. It is also become the lecturer's responsibility to find the solutions for the students. Below are the efforts to solve their problems.

Some solutions are suggested for the students to overcome the speaking problems. Those are described below.

a. The students practice speaking in front of the mirror.

b. The students should practice a conversation with their friends regularly.

c. The students need to watch YouTube to know the correct pronunciation from the native speakers

d. Listen to the tutor explanation from English learning group WhatsApp.

e. Try to use some applications to practice speaking which can be downloaded in play store from their smartphones. Some applications can be used to train students' pronunciation and others can be used to have an oral communication with robotic application.

Some solutions are also compiled for students to overcome the listening problems. The solutions are as follows.

a. For the listening activity in the classroom, the students or lecturers should prepare an adequate sound system.

b. Rearrange or organize the students' seat in order to get a better and comfortable position to listen the audio.

c. The students' way to solve their problem on listening is listen to English music every day

d. Listen to English video which is posted in social media such as Facebook and Instagram

e. Listen to some English materials from native speakers in YouTube

f. Watch English news in television or YouTube.

g. Watch English movie and try to turn off the subtitles.

h. Access some website addresses which contain many listening materials like www.elllo.org

The next solutions are about the efforts to overcome problems faced by students in writing. The efforts are listed below.

a. The alternative for improving their writing skill is writing a story in a diary book

b. Try to write with the true grammar

c. Try to use new vocabularies.

d. Use grammarly application to check the students' grammar in writing.

e. Make a WhatsApp group to communicate by using English in written mode. 
f. Try to use some applications to practice writing skill especially in texting which can be downloaded in play store from their smartphones. This application is robotic application which can be invited to have written communication.

The last problem is related to reading skill. Some alternatives are given to students in resolving the problems.

a. Use social media as their media to study, so the students are interested to learn.

b. Follow English learning accounts and foreigners in Instagram, twitter, and Facebook.

c. Read the English material posts from those accounts.

d. Try to comprehend the text and understand the meaning.

\section{Discussion}

\section{The ways of generation $Z$ of English Education Department students at IAIN Kudus learn English}

In the past, the students use books, games, tape recorder to learn English and improve their abilities especially the communicative competence in English. It is very different with the learning style of the generation in this era. The generation $\mathrm{Z}$ students often use the technology to learn English. To improve their English competence such as listening, speaking, reading, and writing, they use their handy gadgets. It's very easy and simple for them to get English materials. By using their gadgets, they can access some applications through internet.

Since the generation $\mathrm{Z}$ students like to communicate digitally, they can't be separated with their gadgets. It's not surprised that generation $\mathrm{Z}$ spent most of their times using gadgets. It becomes one of the characteristics of generation Z. As stated by Hinduan et al in Suganda (2018), 99\% of generation $Z$ students in Indonesia have smartphones. Most of them use their smartphones to access social media for entertainment and learning.

Besides to get entertainment, they use their smartphones for learning. The reason why they use modern and handy gadgets to learn English is they think that using gadgets is the easier way to study and simple to bring along. They can get lesson materials easily and study it every time and everywhere. They often access social media such as Instagram, twitter, Facebook, YouTube, WhatsApp, and Line. They also access e-book from internet to study.

The students use instagram to study English. They follow some English accounts in Instagram which post any English materials. Those accounts' names are BBC Learning English, English Grammar and Idiom, Light Tone English, etc. The English materials are vocabularies, speaking from native speaker, grammar, idioms, and some quizzes about arrange the words, idioms, and English Grammar.

Besides using Instagram, students also improve their skills by watching YouTube. There are so many videos from native speakers that explain how to pronounce the words well. The materials of the videos from native speakers can be in the form of dialogue/conversation, monologue, speech, news, or some tips or ways to pronounce and others. By watching and listening to the videos in YouTube, the students can repeat after the native speaker speaks, pronounce it like the native speaker, and have an exercise by themselves. It really facilitates them to improve their speaking. Not only for speaking, they use YouTube as their media to improve their listening skill too. They listen to the native and try to understand the native utterances. 
The other social media used by the students are Facebook, twitter, and line. They use those social media to communicate and have interaction with foreigners. They look for some foreigners in those social media. Then they follow their accounts or add as friends so that they can have a chit chat with them. The foreigners are from Australia, India, America, Thailand, and many else.

Not only social media which involve many people to interact each other but also electronic book is used by the students. The students use e-book as their media to study because the quality of e-book is the same with the book. It is easier than traditional book because we can find any kinds of e-book easily in the internet. After downloading the e-book, the students can read it in their gadgets. So, they should not go to the library and look for any books there. The use e-book itself is not the same with the previous media. By using ebook they can add some knowledge about English. In addition, it can also train their reading skill.

The most common social media used by not only students but almost everyone in the world is WhatsApp. The students also use WhatsApp for studying English. They join the English learning group in WhatsApp. There is a teacher in that group who comes from pare. The teacher teaches how to speak in British accent. Then, he gives them some materials also about pronunciation, phonetic symbols, and many else.

The students also use their gadgets to look for the English materials about listening. They will use gadget like YouTube, Google, and other websites. They access it to improve their competences by studying at home by themselves and to help them finish their homework.

\section{The difficulties in learning English encountered by Generation $Z$ of English Education Department students at IAIN Kudus}

In every learning, the learners will face some difficulties so do the students of gen Z. Even though they are gen $Z$ who are digitally native, they also find some difficulties in learning English. The difficulties lie on the language competences such as listening, speaking, reading, and writing.

Based on the results of this research, the students have difficulties mostly in speaking skill. The second problem is they have difficulties in writing. Then, in the third rank is they have problems in those four skills: listening, speaking, reading, and writing. Next, it is followed by the difficulties in listening skill. The last, in the lowest level, students have a problem in reading skill. Those problems will be elaborated below.

a. The students have difficulties in speaking because of some reasons. Most of them are not confident to speak up. They also never practice English conversations each other. Therefore, it makes them so hard to speak English. Some of them are lack in vocabularies. Some of them are also confuse what should they speak because they don't know the grammar. They are not good at grammar. Besides that, the difficult subject or materials also become the reason of this problem. In this semester, the students get the subject of speaking for academic purposes. They feel it is a difficult subject since they are demanded to speak in different situation. They have to speak for English debate. It is very hard for some of the students.

b. The second problem is writing. They find difficulties in writing because they are lack of vocabularies. Some students are not good in grammar. Because of these two 
reasons they cannot compose a good writing. They are confused how to arrange the sentence well and how to make the sentence with the correct grammar.

c. The third problem is some students have difficulties in all skills. Those are listening, speaking, reading, and writing. Actually every skills are related each other. If the students have a trouble in one of the skills, it will give impact also to the other skills. For example, if the students have problems especially in receptive skill such as listening and reading, it will give impacts to their productive skills such as speaking and writing. If the students have problems in receiving the input, they will have a trouble in produce the expressions.

d. Listening lies on the fourth rank of the problems faced by students. They couldn't understand the speaker utterances. The accent or pronunciation of the native speaker is not clear. The next factor is due to the speedy delivery and length of the listening. The students are not able to focus on something (English listening materials) for a long time. Many new words or unfamiliar vocabularies and terminologies become the serious factor as well. The last factor is the limited facility for listening in the campus. It has been reported above that the facilities and infrastructure in IAIN Kudus especially English Department of Tarbiyah faculty are inadequate yet. The English Department or IAIN Kudus haven't has a language laboratory. The lecturer has to run the listening lesson in a classroom without computer and sound system. The lecturers should prepare the equipment by themselves.

e. The last problem is reading skill. Actually it is not a significant problem since there is only one student who has problem in reading. The reason is because the student didn't know how to spell it and pronounce it well. There are some vocabularies are the same to pronounce it. The student sometimes confuse with it. This problem is almost the same or similar to speaking problem. The student should learn how to pronounce, how to speak, and differentiate the pronunciation of the same words. Reading skill belongs to receptive skill. We can get many input from this skill by reading English texts. This input will be used to support the productive skill that is writing skill.

\section{The solutions to overcome the difficulties given to generation $\mathrm{Z}$ of English Education Department students at IAIN Kudus}

Some solutions, alternatives, and efforts are compiled for the students to overcome the problems. Those solutions or alternatives are arranged by the students themselves and the researchers as well. The students can practice those suggestions to resolve their problems.

Below are some solutions to resolve the speaking problems.

a. The students practice speaking in front of the mirror.

b. The students should practice a conversation with their friends regularly.

c. The students need to watch YouTube to know the correct pronunciation from the native speakers

d. Listen to the tutor explanation from English learning group WhatsApp.

e. Try to use some applications to practice speaking which can be downloaded in play store from their smartphones. Some applications can be used to train students' pronunciation and others can be used to have an oral communication with robotic application. 
By applying those suggestions, the students can overcome their speaking problems and improve their speaking skills. The students may use some Artificial Intelligences or robotics application to improve speaking skills.

Meanwhile, several suggestions are prepared for listening problem. Since listening is receptive skill, it is important to improve the skill. The ability in listening skill will influence the speaking skill as a productive skill. The solutions are as follows.

a. For the listening activity in the classroom, the students or lecturers should prepare an adequate sound system.

b. Rearrange or organize the students' seat in order to get a better and comfortable position to listen the audio.

c. The students' way to solve their problem on listening is listen to English music every day

d. Listen to English video which is posted in social media such as Facebook and Instagram

e. Listen to some English materials from native speakers in YouTube

f. Watch English news in television or YouTube.

g. Watch English movie and try to turn off the subtitles.

h. Access some website addresses which contain many listening materials like www.elllo.org

The main point to improve listening skill is always practice to listen English spoken materials. Those include English news, speech, conversation, movie, and song. The more the students receive English input, the more they can speak.

The next discussion is the solutions about the efforts to overcome problems faced by students in writing. Writing belongs to productive skill. The students should produce an English writing. It is become the third major problem of the students. The efforts to overcome the problems are listed below.

a. The alternative for improving their writing skill is writing a story in a diary book

b. Try to write with the true grammar

c. Try to use new vocabularies.

d. Use grammarly application to check the students' grammar in writing.

e. Make a WhatsApp group to communicate by using English in written mode.

f. Try to use some applications to practice writing skill especially in texting which can be downloaded in play store from their smartphones. This application is robotic application which can be invited to have written communication.

If the students are already able to make a simple writing, the next step is advance writing. For the advance writing, the students have to make an academic writing. It is a writing which discusses about a topic or issue and should arrange scientifically.

The last problem is related to reading skill. Reading skill also belongs to receptive skill. It is how the students get the input of English from the written sources. It is also an important skill since it will influence the ability of other skill that is writing skill. Writing skill is productive skill as the product from reading skill which give input to the students. Some alternatives are given to students in resolving the problems.

a. Use social media as their media to study, so the students are interested to learn.

b. Follow English learning accounts and foreigners in Instagram, twitter, and Facebook. 
c. Read the English material posts from those accounts.

d. Try to comprehend the text and understand the meaning

For the students who have problems in those four skills simultaneously, they should apply all of those solutions or suggestions for each skill. Those who get problems in all of the skills need many efforts to overcome their problems. It can be started from the receptive skills first. Students should improve their competence in listening and reading. Then, they should improve the productive skills. Those are speaking and writing. As generation $\mathrm{Z}$ students, they can use many kinds of technology to learn English especially in four skills: listening, reading, speaking, and writing. As the explanation given above, they can download many applications to improve English competence. It will be very easy to learn as those applications can be saved in their handy gadgets.

\section{CONCLUSION}

There are 23 students or $60 \%$ of English Department students use gadgets to study English. Most of them learn English through social media by accessing the internet. The second way to learn English is by using gadgets and books. There is around 25\% of English Department students or 10 students use gadgets and books. The students combined both of them (book and gadget) to get better knowledge in English. The third way is using book to learn English. There are some students which only use books as their media to study. It is around 15\% of English Department students or 6 students using that media.

The first problem is the students have difficulty in speaking. It is $50 \%$ of the students or 20 students. The second problem is the difficulty in writing. There are $17 \%$ of the students or 7 students faced this problem. The third problem is the difficulty in those four skills. There are $17 \%$ of the students or 7 students have a problem in four of them such as listening, speaking, reading, and writing. The fourth is listening. There are 4 students or $10 \%$ of the students have a problem in listening skill. The last is reading. The rest is $6 \%$ of the students or only 1 student who has problem in reading skill.

Some solutions have been elaborated to overcome the problems encountered by the gen $\mathrm{Z}$ students in learning English. Those solutions were given in details for each language skills: listening, speaking, reading, and writing. It is hoped that the students can overcome their problems and improve their English competences by applying those solutions.

\section{REFERENCES}

Ahmed, Sabri Thabit Saleh and Sunil V. Pawar. (2018). "Communicative Competence in English as a Foreign Language: Its Meaning and the Pedagogical Considerations for its Development,"An International, Open Access, Peer Reviewed, Refereed, E-Journal in English, vol. II, no. VI, pp. 301-312.

Arikunto, Suharsimi. (2010). Prosedur Penelitian Suatu pendekatan Praktek, Jakarta: Rineka Cipta.

Gaidhani, Shilpa, Lokesh Arora, and Bhuvanesh Kumar Sharma. (2019). "Understanding the Attitude of Generation Z Towards Workplace," International Journal of Management, Technology and Engineering, vol. IX, no. 1, pp. 2804-2012. 
Sadiku, Lorena Manaj. (2015). "The Importance of Four Skills Reading, Speaking, Writing, Listening in a Lesson Hour," European Journal of Language and Literature Studies, vol. 1, no. 1, pp. 29-31.

Saville-Troike, Muriel. (2006). Introducing Second Language Acquisition. UK: Cambridge University Press.

Suganda, Tarkus. (2018). "Pengelolaan Pembelajaran Zaman Now (Generasi Z),"in the Seminar Pembelajaran Bagi Generasi Z di Stipar Yapari Bandung, pp. 1-11.

Sugiyono. (2015). Metode Penelitian Kombinasi (Mixed Methods). Bandung: Alfabeta.

Yufrizal, Hery. (2017). "Teachers and Students' Perceptions of Communicative Competence in English as A Foreign Language in Indonesia," Academic Journals, vol. 12 , no. 17 , pp. $867-883$

\section{ACKNOWLEDGEMENT}

I express my gratitude to all students of English Department IAIN Kudus especially third semester English students of TBI-A class for helping the researchers to gather the data. My gratitude also goes to the Rector of IAIN Kudus, the Dean of Tarbiyah Faculty, and the Chief of English Department who have given permission to the researchers to conduct this study. 